\title{
Person Deixis in Frozen Movie Script by Sorrow
}

\author{
Ayu Meita Puteri Siregar ${ }^{l}$ \\ ${ }^{1}$ State Islamic Higher Education of Mandailing Natal, Sumatra Utara, Indonesia; \\ Siregarmeita@gmail.com
}

\begin{abstract}
This study aims at describing the types of personal deixis and finding the reference of personal deixis. The object to be analyzed is personal deixis in the form of words. The data in this study was obtained from Frozen Movie Script was taken from dialogue 0:03:39.94 to dialogue 0:11:12.82. The type of the research is descriptive qualitative research. In clarifying the types of personal deixis the researcher uses pragmatics analysis especially deixis theory. Then, the technique of analyzing data are finding the types of personal deixis used in Frozen movie script, describing the reference of the use of personal deixis in movie script of Frozen, drawing the conclusion and suggestion based on the data analysis. The research finding of the study shows that there are three types of personal deixis first personal deixis, second personal deixis and third personal deixis and three kinds of the reference on Frozen Movie include that reference that refers to first person, the reference which refers to second person and the reference which refers to third person. The data of this research consists of 85 personal deixis include that 43 data type of first personal deixis, 22 data type of second personal deixis and 12 data type of third personal deixis.
\end{abstract}

Keywords: Deixis, Movie Analysis, Pragmatics Analysis.

\section{Introduction}

\subsection{Background of the Study}

Communication is one of the most important matters for living things, especially for human. We have to communicate in order to help us fulfill our needs, because we cannot get what we want if we do not say it. Ike Endah Rachmawati (2011) stated that, in such communication, there have to involve at least 2 (two) parties, one party is considered as the speaker and the other one as the addressee. Additionally, it will be better if communication is done communicatively. It is said as communicative if both parties that are involved in the communication understand what is talking about, what the speaker said and what the addressee heard. However, people involved in such communication do not always come from the same background, such as: gender, education, social background and status and also age, so they may use various language styles in speaking and sometimes it makes the sentence 
they utter is hard to understand or seems strange to another party who involves in the speech event.

In having a communicative communication, the right usage of deixis becomes an important factor in building a success communication. Imagine if we say "How are you?" when the lights starts to blackout and there are more than 1 (one) addressee. We may not get a direct answer from the addressees because they cannot get which "you" that we are talking to. Or as if we say: "Are you okay there?" when we ask to our friend in distance. We choose the word "there" instead of "here" because it strongly refers to how the condition of the addressee is. The word you and there here, indicate that there is a system in language which is meant to point person, time and also place, that is called as Deixis. Let's have a look on the following sentences: "I recommend we remove all magic".

The example above shows the word "we" refers to the speaker and refers to the addressee to the hearer. The used of person deixis become flagging topic to be studied, because they are used in almost all aspects in our daily conversation, and it will be more interesting to analyze if it taken from movie script it shown by the language, social life and etc. Furthermore, there is Dwi Setyawati (2013) who has concern the same topic but analyses different object: "the analysis of deixis of the novel "Emma" by Jane Austen". In her analysis she found deixis in four categories, namely: person, spatial, temporal and discourse deixis. In the analysis the writer used several utterances which content deictic expression. Then, the different meanings of the deictic are explained and compared. Furthermore Novie Ima F (2013), in her research: a pragmatic analysis of personal deixis in Iron Lady movie manuscript. The research finding of her study shows that there are three types of personal deixis first personal deixis, second personal deixis and third personal deixis and three kinds of the reference on Iron Lady movie include that reference that refers to first person, the reference which refers to second person and the reference which refers to third person. In this research, I want to explore again about deixis especially on personal deixis using pragmatic approach.

Yule (1996:10) stated that personal deixis, the distinction just described involves person deixis, with the speaker (I) and the addressee (you) mentioned. Person deixis clearly operates on a basic three-part division, exemplified by the pronouns for first person (I), second person (you) and third person (he, she, and it). In many languages these deictic categories of speaker, addressee, and other (s) are elaborated with markers of relative's social status (for example, addressee with higher status versus addressee with lower status). In this section the researcher tries to analyze personal deixis which are found in Frozen Movie Script. For example:

The Troll : "I recommend we remove all magic".

Princess Elsha: “But she won't remember I have powers?

The example above shows the word "we" refers the speaker and refer the addressees to the hearers. To utter the sentence "I recommend we remove all magic". The word "I" here refers to the Troll one of character in this movie as the speaker. The word "I" belongs to singular first person which functions as subject personal pronoun. Then word "We" refer to the king, queen, princess Elsha another characters in Frozen movie and also the troll as the speaker. To find the references of the deictic words, Hurford (1994:66) suggests to use or 
converse the utterance into indirect speech. The indirect speech of the example above will be: The Troll says that, "I recommend we remove all magic".

Based on the phenomena and statement above, the researcher is encouraged to entitle the research as follows: Person Dexis in Frozen Movie Script by Sorrow to analyze more about person dexis. Furthermore this research is directed to be additional source or references for other researcher who wants to scrutinise the same topic.

\subsection{Literary Review}

Schunk stated motivation is the process whereby goal-directed activity is intigated and sustained (Schunk, 2008;4). Frith states motivation can be defined as the internal drive directing behavior towards some end (Frith, 1997:1). It means that motivation is the students' actitivity and behavior in learning English. According to Brennen, Motivation has been defined as the level of effort an individual is willing to expend toward the achievement of a certain goal (Brennen,2011:1). Motivation comes from within a person; therefore, schools' responsibility is to create the conditions that will enhance students' motivation to pursue academic goals actively over a long period of time.

This part relates to the theories that are relevant to the topic of the study. This is too important because this theory can be used as the basic of the analysis of the study. The writer also should find out some related theories that correlate with the study. This chapter explains the definition of pragmatics, the definition of deixis and the five categories of deixis: person deixis, spatial deixis, temporal deixis, discourse deixis and social dexis.

\subsubsection{Pragmatics}

Levinson (1983: 9 in Mey: 37) says "Pragmatics is the study of those relations between language and context that are grammaticalized, or encoded in the structure language". Pragmatics is the study of the conditions of human language uses as these are determined by the context of society. Mey (1993:4) says that "Pragmatics tells us that it is acceptable to use a language in various, unconventional ways, as long as we know, as language user, what we are doing". Thus, pragmatics is the study of utterance meaning, sentences which are used in communication, and also the study of meaning in language interaction between a speaker and a hearer. Depending on all the theories, I know that is concerns with meaning related to the language that is possessed by human groups.

\subsubsection{Dexis}

Deixis is a technical term (from Greek) for one of the most basic things we do with utterances (Yule, 1995: 9). It means "pointing via" language. Any linguistic form used to accomplish this "pointing" is called a deictic expression. Deictic expressions are also sometimes called indexical. They are among the first forms to be spoken by very young children and can be used to indicate people via person deixis (me, you), or location via spatial deixis( here, there), or time via temporal deixis (now, then) or discourse analysis or demonstrative article or discourse deixis (this, that, these, those).

Deixis signals a referent and it relates that referent to a common ground shared by the speaker and the addressee. It is the ability to situate the speaker and hearer in relation to one another and to the world around them. Levinson (1983: 55) says that deixis belongs within 
the domain of pragmatics, because it directly concerns the relationship between the structure of languages and contexts in which they are used. Lyon (1983: 275) argues that the notion of deixis (which is merely the Greek word for 'pointing' or 'indicating' it becomes a technical term of grammatical theory) is introduced to handle the 'orientational' features of language which are relative to the time and place of utterance.

Within linguistic view, deixis refers to the phenomenon where in understanding the meaning of certain words and phrases in an utterance requires contextual information. Then, deixis can give interpretation to the context of the utterance, such as who is speaking, the time or place of speaking, the gesture of the speaker, the current location in the discourse and the topic of the discourse.

According to James (1983:63) Deictic word is one which takes some element of its meaning from the situation (i.e. the speaker, the addressee, the time and the place) of the utterance in which it is used. Deictic expression is an expression that gets it is directly from the utterance context that makes reference to one or more of the roles in the utterance context: the speaker, the hearer, the location, or the time. Wagiman in Dwi Setyawati (2013: 24) says that deictic words occur in utterance meaning. In utterance meaning, there are words of which referents are determined by the specific context in which a speaker converses with a hearer about a particular topic of conversation, for example:

The Troll : "I recommend we remove all magic". Even memories of magic to be safe. But don't worry, I'll leave the fun. She will be okay.

Princess Elsha : "But she won't remember I have powers?

King/ Elsha's father : It's for the best. Listen to me, Elsha. Your power will only grow.

This conversation is between The Troll, Princess Elsha, and King as Princess Elsha's King. They were talking about Princess Elsha's power that has makes Princess Anna got a sick. It has clear contexts there is (I) refers to Troll, (we) involve all characters that have been there in that situation. It refer to Troll as a traditional healer, king, Princess Elsa and queen. Then the next sentences which comes from princess Elsha's spoken (She) here is refers to Princess Anna. Deixis implicates not only the characteristic functions of the demonstrative pronouns but also tense and person, and a number of other syntactically relevant features of the context of utterance. As quoted from Levinson's book "Pragmatics" there are five kinds of deixis, they are: person deixis, time deixis, place deixis, discourse deixis and social deixis. Then, citation from Yule's book "pragmatics" there are three kinds of deixis they are: person deixis, spatial deixis and temporal deixis.

\subsubsection{Categories of Dexis}

\subsubsection{Person Dexis}

Person deixis clearly operates on a basic three part division exemplified by the pronouns for first person $(I)$, second person (you), and third person (he, she or it). According to Yule (1996: 10) "The choice of one form will certainly communicative something (not directly said) about the speaker's view of his or her relationship with the addressee." Levinson (1983: 62) states: Person deixis concerns with the encoding of the role of participants in the speech 
event, in which the utterance in question is delivered: the category first person is the grammaticalization of the speaker's reference to himself, second person the encoding of reference to one or more addresses and third person the encoding of reference to persons and entities which are neither speakers nor addresses of the utterance in question. According to Levinson above, person deixis clearly operates on basic three part division exemplified by the pronouns for first person( I), second person (you) and third person (he, she or it). On the other hand, expressions like this person, this man, the car, these houses, etc are also deictic because they require situational information for the listener to make out the referents or the meanings.

Table 1: Singular and plural pronoun

\begin{tabular}{lll}
\hline Pronoun & Singular & Plural \\
\hline First & I & We \\
\hline Second & You & You \\
\hline Third & He, she, it & They \\
\hline
\end{tabular}

Person deixis engages basically the speaker, known as the first person, the addressee, known as the second person, and other significant participants in the speech situation, neither speaker nor hearer; these are known as third person. All of these, they come in singular and plural pronoun. Person deixis is not only referring someone or somebody but also it can refer something. In English, the distinctions are generally indicated by pronouns. It can be included into subject pronoun ( $I$, you, we, they, he, she and it), object pronoun (me, him, her, it, us and them), possessive adjective (my, your, our, their) and possessive pronoun (mine, yours, hers, theirs).

Table 2: Subject Pronoun, Object Pronoun, Possessive Pronoun, and Possessive Pronoun.

\begin{tabular}{llll}
\hline Subject Pronoun & Object Pronoun & $\begin{array}{c}\text { Possessive } \\
\text { Adjective }\end{array}$ & Possessive Pronoun \\
\hline I & Me & My & Mine \\
\hline You & Him & Your & Yours \\
\hline We & Her & Our & Hers \\
\hline They & It & Their & Theirs \\
\hline He & Us & & \\
\hline She & Them & & \\
\hline It & & & \\
\hline
\end{tabular}

\subsubsection{Time Deixis}

Yule (1996) states, Time deixis or Temporal dexis concerns with the encoding of temporal points and spans relative to the time at which an utterance is spoken. Temporal deixis is commonly grammatical zed in deictic adverb of time (like English now and then, yesterday and this year) but above all in tense. English has two basic forms of tenses there are present and past tense. Time or temporal deixis makes ultimate reference to participant role. The use of the proximal form "now" as indicating what is the happening. In contrast to "now", the distal expression "then" applies to both past and future time relative to the 
speaker's present time. The forms of temporal reference are learned a lot later than the deictic expression like tomorrow, today, yesterday, tonight, last week, next week, this week. The all of expression are based on the interpretation of participants on knowing the relevant utterance time.

\subsubsection{Place Deixis}

Levinson (1983:62) states, place deixis concerns with the encoding of spatial locations relative to the location of the participants in the speech event. Probably most languages grammaticalize at least a distinction between proximal (or close to speaker) and distal (or non- proximal, sometimes close to addressee), but many make much more elaborate distinctions so we shall see. Such distinctions are commonly encoded in demonstratives (as in English this vs. that) and in deictic adverbs of place (like English here vs. there)". Spatial deixis show itself principally in the form of location adverbs such as here and there, and demonstrative such as this and that. English has a relatively impoverished place deictic system, with two terms there are proximal and distal. The proximal term here means something like" region relative close to the speaker", and there means "relatively distant from speaker". It is very important to realize that relatively closeness is contextually determined. Here represent an area less than square meter from the speaker is standing or it could be something much large.

\subsubsection{Discourse Deixis}

According Levinson (1983: 85) "Discourse or text deixis concerns the use of expressions within some utterance to refer to some portion of the discourse that contains that the utterance (including the utterance itself), for example: a.This is a great poetry. "This" refers to an upcoming portion of the discourse.

Levinson (1983: 62) states, Discourse deixis deals with "the encoding of reference to portions of the unfolding discourse in which the utterance (which includes the text referring expression) is located" Discourse deixis, somehow, is often compared to anaphora. However, discourse deixis and anaphora is different since discourse deixis is located in a pronoun which refers to a linguistic expression or part of discourse itself, while anaphora is located in a pronoun which refers to the same entity as a prior linguistics expression refers to (Levinson, 1983: 86). Discourse deixis concerns with the use of expression within some utterance to refer to some portions of the discourse that contains the utterance. The deictic word used here are the demonstratives this and that. This can be used to refer to a portion of the discourse and that to a previous portion. Demonstrative article divided into four types there are this, that, these and those (Dwi Setyawati: 2013: 30).

\subsubsection{Social Dexis}

According to Levinson (1985:63), Social deixis concerned with the encoding of destination that are relative to participant roles, particularly aspect of the social relationship holding between speaker and addressee (s) or speaker and some referent. Social deixis also concern with the aspect of sentences that reflect by certain realities of the social situation in which the utterances occurs. For example:

1. King for prince

2. Queen for princess 
In summary, social deixis occurs in many aspect of language usage that depend on the relation (social relationship) but these usage are only relevant to the topic of social deixis in so far as grammaticalized.

\subsubsection{Synopsis of Frozen Movie}

Frozen is a 2013 American $\underline{\text { 3D }}$ computer-animated musical fantasy-comedy film produced by Walt Disney Animation Studios and released by Walt Disney Pictures. It is the 53rd animated feature in the Walt Disney Animated Classics series. Inspired by Hans Christian Andersen's fairy tale The Snow Queen, the film tells the story of a fearless princess who sets off on an epic journey alongside a rugged iceman, his loyal pet reindeer, and a naïve snowman to find her estranged sister, whose icy powers have inadvertently trapped the kingdom in eternal winter.

Frozen movie is story about In the Kingdom of Arendelle, Princess Elsa has the power of freezing and creating ice and snow, and her younger sister Anna loves to play with her. When Elsa accidentally hits Anna on the head with her gift and almost kills her, their parents bring them to trolls that save Anna's life and make her forget the ability of her sister. Elsa returns to the castle and maintain herself recluse in her room with fear of hurting Anna with her increasing power. Their parents die when their ship sinks in the ocean and three years later, the coronation of Elsa forces her to open the gates of her castle to celebrate with the people. Anna meets Prince Hans in the party and she immediately falls in love with him and decides to marry him. But Elsa does not accept the marriage and loses control of her powers freezing Arendelle. Elsa flees to the mountain and Anna teams up with the peasant Kristoff and his reindeer Sven and with the snowman Olaf to seek out Elsa. They find Elsa in her icy castle and she accidentally hits Anna in the heart; now only true love can save her sister from death.

\section{Method}

The methodology of this research is qualitative in nature. Lichtman (2013: 7) explains that in social sciences, qualitative research is about the analysis of phenomena which is not based counting. Merriam (2009: 14) gives four characteristics of qualitative research: "the focus is on process, understanding and meaning; the researcher is the primary instrument of data collection and analysis; the process is inductive; and the product is richly descriptive". According to Saldana (2013: 3), the information collected and analysed. Furthermore, comprises textual materials such as documents or visual materials. Following this concepts, I collected the qualitative data from the script of "Frozen Movie script by Sorrow". Then, the data were analysed descriptively using several utterances which content deictic expression. Then, the different meanings of the deictic are explained and compared.

\subsection{Object of the study}

The object to be analyzed in this study is personal deixis in the form of words. The data in this study was obtained from Frozen Movie Script was taken from dialogue: 0:03:39.94 to dialogue 0:11:12.82. 


\subsection{Data Analysis}

The data of the research are collected by doing the following steps:

a. Watching

Watching the Movie "Frozen" by Jennifer Lee

b. Finding the movie script. I accessed the script from the web. I found the "Frozen" movie script by Sorrow. Furthermore I only take some dialogues; 0:03:39.94 to dialogue 0:11:12.82.

c. Collecting

I collect the data from the utterances which are found in the t movie script by Sorrow; 0:03:39.94 to dialogue 0:11:12.82

d. Classifying

I classify all the data into the utterances contain deixis and do not contain deixis.

To analyze data, I use the following steps: (1) identifying types of deixis used by the characters in the utterances; (2) classifiying the usage of the deixis by the characters into kinds of deixis, namely: person deixis, place deixis, time deixis and discourse deixis. Then, I only focus on Person dexis; (3) analysing the context of the utterances; (4) describing the usage of deixis by the characters and the referent of the deixis focuses on Person dexis; and (5) making conclusion.

\section{Findings and Discussion}

\subsection{Findings}

This research conducts the types of personal deixis and the reference of personal deixis.

Table 3. The use Person Dexis in Frozen Movie script by Sorrow:

\begin{tabular}{|c|c|c|c|c|}
\hline \multirow[t]{2}{*}{ Utterances } & \multicolumn{3}{|c|}{ Types of Person dexis } & \multirow[t]{2}{*}{ References } \\
\hline & $\begin{array}{c}\text { First } \\
\text { Person }\end{array}$ & $\begin{array}{l}\text { Second } \\
\text { Person }\end{array}$ & $\begin{array}{c}\text { Third } \\
\text { Perso } \\
\text { n }\end{array}$ & \\
\hline $\begin{array}{l}\text { I just can't. The sky's awake, } \\
\text { so I'm awake }\end{array}$ & I & & & I refer to Anna \\
\hline So we have to play. & We & & & We refer to Anna and Elsha \\
\hline $\begin{array}{l}\text { Do you want to build a } \\
\text { snowman? }\end{array}$ & & You & & You refer to Elsha \\
\hline $\begin{array}{l}\text { Hi, I'm Olaf and I like warm } \\
\text { hugs. }\end{array}$ & $\mathrm{I}$ & & & I refer to Olaf \\
\hline I love you, Olaf. & I & & & I refer to Anna \\
\hline Al'right. - Catch me! Gotcha! & $\mathrm{Me}$ & & & $M e$ refer to Anna \\
\hline You ok, Anna. I Got you. & I & You & & $\begin{array}{l}\text { You refer to Anna. I refer } \\
\text { to Elsha }\end{array}$ \\
\hline $\begin{array}{l}\text { Elsa, what have you done? } \\
\text { This is getting out of hand! }\end{array}$ & & You & & You refer to Elsha \\
\hline $\begin{array}{l}\text { It was an accident. I'm sorry, } \\
\text { Anna. }\end{array}$ & I & & It & $\begin{array}{l}\text { It refers to Elsha's doing. I } \\
\text { refer to Elsha. }\end{array}$ \\
\hline
\end{tabular}




\begin{tabular}{|c|c|c|c|c|}
\hline $\begin{array}{l}\text { She's ice cold. I know where } \\
\text { we have to go. }\end{array}$ & $\mathrm{I}, \mathrm{We}$ & She & & $\begin{array}{l}\text { She refers to Anna. I refer } \\
\text { to King. We refer to King, } \\
\text { Elsha, and Queen. }\end{array}$ \\
\hline My daughter! & My & & 1 & My refer to King. \\
\hline He is the king! & & $\mathrm{He}$ & 1 & $\mathrm{He}$ refers to King. \\
\hline Shush. I'm trying to listen. & I & & 1 & I refer to one of the Troll \\
\hline Cuties. I'm gonna keep you & You & & 2 & $\begin{array}{l}\text { I refer to one of the Troll. } \\
\text { You refer to Jack and Sven. }\end{array}$ \\
\hline You're Majesty! & You & & 1 & You refer to Elsha. \\
\hline $\begin{array}{l}\text { Born. And they're getting } \\
\text { stronger. }\end{array}$ & & They & 1 & $\begin{array}{l}\text { They refer to Elsha's } \\
\text { power. }\end{array}$ \\
\hline $\begin{array}{l}\text { You are lucky it wasn't her } \\
\text { heart. }\end{array}$ & You & It & 2 & $\begin{array}{l}\text { You refer to King. It refers } \\
\text { to Elsha's magic. Her refers } \\
\text { to Anna. }\end{array}$ \\
\hline Do what you must. & You & & 1 & $\begin{array}{l}\text { You refer to the traditional } \\
\text { healer( Troll) }\end{array}$ \\
\hline $\begin{array}{l}\text { I recommend we remove all } \\
\text { magic, } \\
\text { But don't worry, I'll leave the } \\
\text { fun. }\end{array}$ & I, We, I & & 3 & $\begin{array}{l}\text { I refer to the Troll. We refer } \\
\text { to King, Queen, Elsha and } \\
\text { Troll. }\end{array}$ \\
\hline She will be okay. & & She & 1 & She refers to Anna. \\
\hline $\begin{array}{l}\text { But she won't remember I } \\
\text { have powers? }\end{array}$ & $\mathrm{I}$ & She & 2 & $\begin{array}{l}\text { She refers to Anna. I refer } \\
\text { to Elsha. }\end{array}$ \\
\hline $\begin{array}{l}\text { It's for the best.Listen to me, } \\
\text { Elsa, }\end{array}$ & $\mathrm{Me}$ & It & 2 & $\begin{array}{l}\text { It refers to the handling for } \\
\text { Elsha's power. Me refer to } \\
\text { Elsha's father (King). }\end{array}$ \\
\hline Your power will\only grow. & Your & & 1 & Your refer to Elsha. \\
\hline There is beauty in it... & & It & 1 & It refers to Elsha's power. \\
\hline You must learn to control it. & You & & 1 & You refer to Elsha. \\
\hline Fear will be your enemy. & Your & & 1 & Your refer to Elsha. \\
\hline No. We'll protect her & $\mathrm{We}$ & Her & 2 & $\begin{array}{l}\text { We refer to King and } \\
\text { Queen. Her refers to Elsha. }\end{array}$ \\
\hline $\begin{array}{l}\text { She can learn to control it. I'm } \\
\text { sure. }\end{array}$ & $\mathrm{I}$ & $\begin{array}{l}\text { She, } \\
\text { it }\end{array}$ & 3 & $\begin{array}{l}\text { She refers to Elsa. It refers } \\
\text { to Elsha's power. I refer to } \\
\text { King. }\end{array}$ \\
\hline $\begin{array}{l}\text { We'll lock the gates. We'll } \\
\text { reduce the staff }\end{array}$ & $\mathrm{We}, \mathrm{We}$ & & 2 & $\begin{array}{l}\text { We refer to King and his } \\
\text { staffs. We refer to King and } \\
\text { all his staffs. }\end{array}$ \\
\hline $\begin{array}{l}\text { We will limit her contact with } \\
\text { people }\end{array}$ & $\mathrm{We}$ & Her & 2 & $\begin{array}{l}\text { We refer to King and his } \\
\text { staffs. Her refers to Esha. }\end{array}$ \\
\hline $\begin{array}{l}\text { And keep her powers hidden } \\
\text { from everyone.. }\end{array}$ & & Her & 1 & Her refers to Elsha. \\
\hline
\end{tabular}




\begin{tabular}{|c|c|c|c|c|c|}
\hline $\begin{array}{l}\text { Do you want to build a } \\
\text { snowman? }\end{array}$ & & You & & 1 & You refer to Elsha. \\
\hline $\begin{array}{l}\text { I never see you anymore. } \\
\text { Come out the door. }\end{array}$ & I & You & & 2 & $\begin{array}{l}\text { I refer to Anna. You refer to } \\
\text { Elsha. }\end{array}$ \\
\hline It's like you've gone away. & & You & It & 2 & $\begin{array}{l}\text { It refers to the event. You } \\
\text { refer to Elsha. }\end{array}$ \\
\hline We used to be best buddies & $\mathrm{We}$ & & & 1 & $\begin{array}{l}\text { We refer to Anna and } \\
\text { Elsha. }\end{array}$ \\
\hline $\begin{array}{l}\text { And now we're not. I wish you } \\
\text { would tell me why. }\end{array}$ & $\begin{array}{l}\text { We, I, } \\
\mathrm{Me}\end{array}$ & You & & 4 & $\begin{array}{l}\text { We refer to Elsha and } \\
\text { Anna. I refer to Anna. You } \\
\text { refer to Elsha. Me refer to } \\
\text { Anna. }\end{array}$ \\
\hline $\begin{array}{l}\text { Do you want to build a } \\
\text { snowman? }\end{array}$ & & You & & 1 & You refer to Elsha. \\
\hline $\begin{array}{l}\text { It doesn't have to be a } \\
\text { snowman. }\end{array}$ & & & It, & 1 & $\begin{array}{l}\text { It refers to what will they } \\
\text { do. }\end{array}$ \\
\hline $\begin{array}{l}\text { Conceal it. Don't feel it. Let it } \\
\text { show. }\end{array}$ & & & It, It & 2 & $\begin{array}{l}\text { It refers to the magic. It } \\
\text { refers to Elsha's power. }\end{array}$ \\
\hline $\begin{array}{l}\text { Or ride our bike around the } \\
\text { hall? }\end{array}$ & Our & & & 1 & $\begin{array}{l}\text { Our refer to Anna and } \\
\text { Elsha. }\end{array}$ \\
\hline $\begin{array}{l}\text { Do you want to build a } \\
\text { snowman? }\end{array}$ & & You & & 1 & You refer to Elsha. \\
\hline $\begin{array}{l}\text { Or ride our bike around the } \\
\text { hall? }\end{array}$ & Our & & & 1 & $\begin{array}{l}\text { Our refer to Anna and } \\
\text { Elsha. }\end{array}$ \\
\hline $\begin{array}{l}\text { I think some company is } \\
\text { overdue.. }\end{array}$ & I & & & 1 & I refer to Anna. \\
\hline $\begin{array}{l}\text { I've started talking to the } \\
\text { pictures on the walls. }\end{array}$ & I & & & 1 & I refer to Anna. \\
\hline $\begin{array}{l}\text { It gets a little lonely all these } \\
\text { empty rooms. }\end{array}$ & & & It & 1 & It refers to Anna's feeling. \\
\hline $\begin{array}{l}\text { I'm scared. It's getting } \\
\text { stronger. }\end{array}$ & I & & It & 2 & $\begin{array}{l}\text { I refer to Elsha. It refers to } \\
\text { Elsha's magic. }\end{array}$ \\
\hline $\begin{array}{l}\text { Getting upset only makes it } \\
\text { worse }\end{array}$ & & & It & 1 & It refers to Elsha's magic. \\
\hline $\begin{array}{l}\text { Don't touch me. Please. I don't } \\
\text { want to hurt you }\end{array}$ & Me, I & You & & 2 & $\begin{array}{l}\text { Me refer to Elsha. I refer to } \\
\text { Elsha. You refer to the } \\
\text { King. }\end{array}$ \\
\hline See you in two weeks. & & You & & 1 & You refer to Elsha. \\
\hline Do you have to go? & & You & & 1 & $\begin{array}{l}\text { You refer to King and } \\
\text { Queen. }\end{array}$ \\
\hline You'll be fine, Elsa. & & You & & 1 & You refer to Elsha. \\
\hline Please, $\mathbf{i}$ know you're in there & I & You & & 2 & $\begin{array}{l}\text { I refer to Anna. You refer to } \\
\text { Elsha. }\end{array}$ \\
\hline $\begin{array}{l}\text { People are asking where } \\
\text { you've been, }\end{array}$ & & You & & 1 & You refer to Elsha. \\
\hline
\end{tabular}




\begin{tabular}{|c|c|c|c|c|}
\hline $\begin{array}{l}\text { They say have courage and i'm } \\
\text { trying to... }\end{array}$ & $\mathrm{I}$ & They & 2 & $\begin{array}{l}\text { They refer to people. I refer } \\
\text { to Anna. }\end{array}$ \\
\hline $\begin{array}{l}\text { I'm right out here for you. Just } \\
\text { let me in. }\end{array}$ & $\mathrm{I}, \mathrm{Me}$ & & 2 & $\begin{array}{l}\text { I refer to to Anna. } M e \text { refer } \\
\text { to Anna. }\end{array}$ \\
\hline We only have each other. & $\mathrm{We}$ & & 1 & We refer to Elsha and Anna \\
\hline It's just you and me. & $\begin{array}{l}\text { You, } \\
\text { Me }\end{array}$ & & 2 & $\begin{array}{l}\text { You and } M e \text { refer to Anna } \\
\text { and Elsha. }\end{array}$ \\
\hline What are we gonna do? & $\mathrm{We}$ & & 1 & $\begin{array}{l}\text { We refer to Anna and } \\
\text { Elsha. }\end{array}$ \\
\hline $\begin{array}{l}\text { Do you want to build a } \\
\text { snowman? }\end{array}$ & You & & 1 & You refer to Elsha. \\
\hline $\begin{array}{c}\text { Total: } \\
\end{array}$ & $=85$ of & on dex & & \\
\hline
\end{tabular}

After I analyzed and classified of person dexis from this script, I conclude the data as bellow:

Table 4. Types of person dexis

\begin{tabular}{|c|c|c|}
\hline First Person dexis & Second Person dexis & Third Person dexis \\
\hline 43 & 22 & 12 \\
\hline
\end{tabular}

\subsection{Discussion}

According to my analyzing, I will give the explanations of my data about the types of personal deixis and the reference of personal deixis.

\subsubsection{First person deixis}

- "I just can't. The sky's awake, so I'm awake"

a. The Type

The deixis in the utterance is personal pronoun $\mathbf{I}$. It is singular first personal deixis type. Personal pronoun $\mathbf{I}$ in that sentence refer to the speaker who utters the utterance. In this sentence, personal pronoun I refers to Anna. Personal pronoun I is used to show that Anna just can't. The sky's awake, so Anna is awake. Therefore, the personal pronoun I functions as a subjective personal pronoun.

b. The Reference

The utterance above is conversed into indirect speech to find out the reference of personal pronoun . Therefore, the word $\mathbf{I}$ is substituted by Anna. So, the reference of personal pronoun I is Anna. Because Anna is the speaker that utters that spoken told to Elsha that she is awake. From the data above, it can be analyzed that personal pronoun I refer to Anna.

- We'll protect her

a. The Type

Personal pronoun which is found in this utterance is We. Personal pronoun We here, refer to King and Queen as Elsha and Anna's parents. Thus, the type that found in this utterance 
is plural first personal deixis. The word We which has function as subjective personal pronoun.

b. The Reference

The utterance above is conversed into indirect speech to find out the reference of personal pronoun We. From the data above, the personal pronoun We substitute King and Queen. So, the reference of personal pronoun We are King and Queen. From the data above, it can be analyzed that personal pronoun We refer to King and Queen. The word We is used to confirm to the traditional healer that King and Queen can control Elsha's power.

\subsubsection{Second Person Deixis}

- Your power will only grow.

a. The Type

The deictic word in the utterance above is the word your. The type of the word your is second person deixis. The word your which has a function as possessive adjective. The word your refers to the possessive adjective pronoun of Elsha as the addressee.

b. The Reference

The utterance above is conversed into indirect speech to find out the reference of personal pronoun your. Therefore, the personal pronoun your in the utterance above utters by traditional healer (Troll) that refers to Elsa. So, the reference of pronoun your is Elsha. The Troll explains that Elsha's power will only grow.

- Do you want to build a snowman?

a. The Type

Personal pronoun you above suggests the second personal deixis type. You itself is the person addressed. In this verse, personal pronoun you refers to Elsha. In the utterance uses personal pronoun you to address Elsha. It is subjective pronoun function.

b. The Reference

The utterance above is conversed into indirect speech to find out the reference personal pronoun you. Therefore, personal pronoun you refers to Elsha. So, the reference of personal pronoun you is Elsha. It utters by Anna that try to ask Elsha to play with her.

\subsubsection{Third Person Deixis}

- But she won't remember I have powers?

a. The Type

The deictic words in the utterance above is the word She. The type of the word She is singular third person deixis. The word She has function as subjective pronoun. It refers to Anna.

b. The Reference

The utterance above is conversed into indirect speech to find out the reference of personal pronoun She. The reference of personal pronoun She is Anna that utters by Elsha to confirm that Anna won't know about Elsha's magic. 
- And keep her powers hidden from everyone.

a. The Type

The deictic words in the utterance above is the word Her. The type of the word Her is singular third person deixis. The word Her has function as the possessive adjective pronoun of Elsha.

b. The Reference

The utterance above is conversed into indirect speech to find out the reference of personal pronoun Her. The reference of personal pronoun Her is Elsha that utters by the King that ask to all his Staff to control Elsha's magic. Her here explain about Elsha's power.

\section{Conclusion}

Based on the data analysis and discussion, I conclude that there are three types of person deixis that is used in Frozen Movie script based on the dialogue 0:03:39.94 to dialogue 0:11:12.82 namely first person deixis, second person deixis and third person deixis. There are 85 data of personal deixis include that 43 data type of first personal deixis, 22 data type of second personal deixis and 12 data type of third personal deixis. Moreover, there are also three kinds of the reference on Frozen Movie script based on the dialogue 0:03:39.94 to dialogue $0: 11: 12.82$, namely the reference that refers to first person, the reference which refers to second person and the reference which refers to third person.

For further research, the next researchers especially who takes the similar research do more complete innovations. Therefore, the other 11 researchers are suggested to investigate such kind of research in different object. 


\section{References}

Ima, Novie Fatkhunurohmah. 2013. A Pragmatic Analysis of Personal Deixis In Iron Lady Movie Manuscript. Thesis. School of Teacher Training and Education. Surakarta: Muhammadiyah University Press.

Levinson, Stephen C. 1983.Pragmatics. London: Cambridge University Press.

Leech, Ceofrich. 1983. Principles of Pragmatics. Cambridge: Cambridge University Press.

Lyons, John. 1983. Introductions to Theoretical Linguistics. London: Cambridge University Press.

Mey, Jacob, L. 1993. Pragmatics: An Introduction. Oxford UK and CambridgeUniversity USA: Blackwell.

Merriam, Sharan B. 2009. Qualitative Research: a guide to design and implementation. San Francisco: John Willey and Sons, Inc.

Nababan, P. W. J. 1987. Ilmu Pragmatik (Teori danPenerapannya). Jakarta. Debdikbud.

Robert, K. 2011.Qualitative Research from Start to Finish. New York: The Guilford Press.

Rosmawaty. (2013). Analysis the Use of the Kind of Deixis on 'Ayat-Ayat Cinta' Novel by Habiburrahman El-Shirazy. Medan: Department of Indonesian Education State University of Medan International Journal of Humanities and Social Science Vol. 3 No. 17

Saldana, Johnny. 2011. Fundamentals of qualitative Research: Understanding Qualitative Research. New York: Oxford University Press.

Samosir, Nitabonita. (2013). An Analysys Of Deixis In The Article Of The Jakarta Post. Medan: Publication Article. English Department, Faculty Of Language And Arts State University Of Medan (Unimed)

Setyawati, Dwi. (2013) Analysis Of Deixis Of The Novel "Emma" By Jane Austen Publication

Yule, George. (1996). Pragmatics (Oxford Introductions to Language Study). Oxford University Press.

Yule, George. (2006). Pragmatik. Yogyakarta: Pustaka Pelajar. (Translation) 


\section{Appendices}

Frozen" movie script by Sorrow. (Dialogue 0:03:39.94 to dialogue 0:11:12.82)

Dialogue: 0,0:03:39.94,0:03:42.05,Default,,0,0,0,,Elsa. Psst

Dialogue: 0,0:03:43.70,0:03:45.17,Default,,0,0,0,,Elsa!

Dialogue: 0,0:03:45.49,0:03:47.60,Default,,0,0,0,,Wake up. Wake up. Wake up.

Dialogue: 0,0:03:47.87,0:03:50.64,Default,,0,0,0,,Anna, go back to sleep.

Dialogue: 0,0:03:51.44,0:03:56.02,Default,,0,0,0,,I just can't. The sky's awake, so I'm awake,

Dialogue: 0,0:03:56.06,0:03:58.56,Default,,0,0,0,,so we have to play.

Dialogue: 0,0:03:58.60,0:04:01.06,Default,,0,0,0,,..Go play by yourself.

Dialogue: 0,0:04:07.00,0:04:09.44,Default,,0,0,0,,Do you want to build a snowman?

Dialogue: 0,0:04:10.72,0:04:12.96,Default,,0,0,0,,Come on, come on, lcome on, come on.

Dialogue: 0,0:04:16.76,0:04:19.74,Default,,0,0,0,,Do the magic! Do the magic!

Dialogue: 0,0:04:24.76,0:04:25.74,Default,,0,0,0,,- Ready? Uhhm...

Dialogue: 0,0:04:30.08,0:04:32.42,Default,,0,0,0,,This is amazing!

Dialogue: 0,0:04:34.70,0:04:36.54,Default,,0,0,0, Watch this!

Dialogue: 0,0:04:44.46,0:04:47.50,Default,,0,0,0,,Hi, I'm Olaf and I like warm hugs.

Dialogue: 0,0:04:47.58,0:04:49.84,Default,,0,0,0,,I love you, Olaf.

Dialogue: 0,0:05:01.16,0:05:04.10,Default,,0,0,0,--Al'right. - Catch me! Gotcha!

Dialogue: 0,0:05:04.78,0:05:07.66,Default,,0,0,0,,- Again! Wait!

Dialogue: 0,0:05:08.56,0:05:10.76,Default,,0,0,0,,Slow down!

Dialogue: 0,0:05:12.44,0:05:14.88,Default,,0,0,0,,Anna!

Dialogue: 0,0:05:19.12,0:05:20.86,Default,,0,0,0,,Anna?

Dialogue: 0,0:05:22.96,0:05:25.22,Default,,0,0,0,,mama! papa!

Dialogue: 0,0:05:33.10,0:05:36.06,Default,,0,0,0,,You ok, Anna. I Got you.

Dialogue: 0,0:05:37.36,0:05:40.84,Default,,0,0,0,,Elsa, what have you done? This is getting out of hand!

Dialogue: 0,0:05:40.87,0:05:44.26,Default,,0,0,0,,It was an accident. I'm sorry, Anna.

Dialogue: 0,0:05:44.94,0:05:48.38,Default,,0,0,0,,- She's ice cold. I know where we have to go.

Dialogue: 0,0:06:07.96,0:06:09.64,Default,,0,0,0,,Ice?

Dialogue: 0,0:06:09.68,0:06:11.72,Default,,0,0,0,,Faster, Sven!

Dialogue: 0,0:06:13.74,0:06:15.28,Default,,0,0,0,,Sven!

Dialogue: 0,0:06:18.25,0:06:20.28,Default,,0,0,0,,Please... Help!

Dialogue: 0,0:06:21.04,0:06:22.59,Default,0,0,0,,My daughter!

Dialogue: 0,0:06:33.11,0:06:35.21,Default,,0,0,0,,He is the king!

Dialogue: 0,0:06:37.19,0:06:39.00,Default,,0,0,0,,Trolls...?

Dialogue: 0,0:06:39.03,0:06:41.49,Default,,0,0,0,,Shush. I'm trying to listen.

Dialogue: 0,0:06:41.89,0:06:45.13,Default,,0,0,0,,Cuties. I'm gonna keep you.

Dialogue: 0,0:06:45.65,0:06:47.34,Default,,0,0,0,,You'r Majesty!

Dialogue: 0,0:06:47.37,0:06:49.82,Default,,0,0,0,,Born with the powers or cursed?

Dialogue: 0,0:06:49.83,0:06:52.29,Default,,0,0,0,,Born. And they're getting stronger.

Dialogue: 0,0:06:55.17,0:06:57.97,Default,,0,0,0,,You are lucky it wasn't her heart. 
Dialogue: 0,0:06:58.01,0:07:00.77,Default,,0,0,0,,The heart is not so easily changed,

Dialogue: 0,0:07:00.81,0:07:03.43,Default,,0,0,0,,But the head can be persuaded.

Dialogue: 0,0:07:03.47,0:07:05.24,Default,,0,0,0,,Do what you must.

Dialogue: 0,0:07:05.27,0:07:08.08,Default,,0,0,0,,I recommend we remove all magic,

Dialogue: 0,0:07:08.11,0:07:11.71,Default,,0,0,0,,even memories of magic to belsafe...

Dialogue: 0,0:07:13.21,0:07:16.77,Default,,0,0,0,,But don't worry, I'll leave the fun.

Dialogue: 0,0:07:21.37,0:07:23.40,Default,,0,0,0,,She will be okay.

Dialogue: 0,0:07:23.43,0:07:26.37,Default,,0,0,0,But she won't remember I havelpowers?

Dialogue: 0,0:07:26.41,0:07:29.31,Default,,0,0,0,-- It's for the best.IListen to me, Elsa,

Dialogue: 0,0:07:29.37,0:07:32.55,Default, 0,0,0,,your power will lonly grow.

Dialogue: 0,0:07:33.39,0:07:35.89,Default, ,0,0,0,, There is beauty in it...

Dialogue: 0,0:07:36.97,0:07:39.69,Default,,0,0,0,,But also great danger.

Dialogue: 0,0:07:39.89,0:07:42.43,Default, $0,0,0$, ,You must learn to control it.

Dialogue: 0,0:07:42.47,0:07:45.73,Default,,0,0,0,,Fear will be your enemy.

Dialogue: 0,0:07:48.39,0:07:51.85,Default,,0,0,0,,No. We'll protect her. She can learn to control it. I'm sure.

Dialogue: 0,0:07:52.17,0:07:53.81,Default,,0,0,0,,Until then,

Dialogue: 0,0:07:53.85,0:07:57.17,Default,,0,0,0,,We'll lock the gates.We'll reduce the staff

Dialogue: 0,0:07:57.51,0:08:00.55,Default,,0,0,0, We will limit her contact with people

Dialogue: 0,0:08:00.67,0:08:03.57,Default,,0,0,0, and keep her powers hidden from everyone...

Dialogue: 0,0:08:06.31,0:08:08.57,Default,,0,0,0,,including Anna.

Dialogue: 0,0:08:18.73,0:08:20.55,Default,,0,0,0,,Elsa?

Dialogue: 0,0:08:22.59,0:08:25.73,Default,,0,0,0,,Do you want to build a snowman?

Dialogue: 0,0:08:25.97,0:08:28.91,Default,,0,0,0,,Come on let's go and play.

Dialogue: 0,0:08:29.21,0:08:32.67,Default,,0,0,0,,I never see you anymore. Come out the door.

Dialogue: 0,0:08:32.70,0:08:35.71,Default,,0,0,0,,It's like you've gone away.

Dialogue: 0,0:08:35.74,0:08:38.03,Default,,0,0,0, We used to be best buddies

Dialogue: 0,0:08:38.25,0:08:43.31,Default,,0,0,0,,And now we're not. I wish you would tell me why.

Dialogue: 0,0:08:43.79,0:08:46.85,Default,,0,0,0,,Do you want to build a snowman?

Dialogue: 0,0:08:46.89,0:08:48.91,Default,,0,0,0,,It doesn't havelto be a snowman.

Dialogue: 0,0:08:48.93,0:08:50.97,Default,,0,0,0,,Go away, Anna.

Dialogue: 0,0:08:51.18,0:08:53.97,Default,,0,0,0,,... Okay bye.

Dialogue: 0,0:09:00.02,0:09:02.89,Default,,0,0,0,,The gloves will help. ISee...

Dialogue: 0,0:09:02.92,0:09:05.66,Default,,0,0,0,-- Conceal it.IN- Don't feel it.

Dialogue: 0,0:09:05.70,0:09:07.72,Default,,0,0,0,,Don't let it show.

Dialogue: 0,0:09:10.28,0:09:13.13,Default,,0,0,0,,Do you want to build a snowman?

Dialogue: 0,0:09:13.17,0:09:15.98,Default,,0,0,0,,Or ride our bike around the hall?

Dialogue: 0,0:09:16.46,0:09:18.63,Default,,0,0,0,,I think some company is overdue...

Dialogue: 0,0:09:18.66,0:09:21.68,Default,,0,0,0,,I've started talking to the pictures on the walls.

Dialogue: 0,0:09:21.72,0:09:22.83,Default,,0,0,0,,Hang in there, Joan. 
Dialogue: 0,0:09:22.86,0:09:26.42,Default,,0,0,0,,It gets a little lonely all these empty rooms.

Dialogue: 0,0:09:26.46,0:09:30.14,Default,,0,0,0,,Just watching the hours tick by.

Dialogue: 0,0:09:35.32,0:09:37.96,Default,,0,0,0,,I'm scared. It's getting stronger.

Dialogue: 0,0:09:38.00,0:09:39.27,Default,,0,0,0,,Getting upset only makes it worse.

Dialogue: 0,0:09:39.28,0:09:40.57,Default,,0,0,0,,Calm down.

Dialogue: 0,0:09:40.60,0:09:44.78,Default,,0,0,0,,No. Don't touch me. Please. I don't want to hurt you.

Dialogue: 0,0:09:52.40,0:09:54.34,Default,,0,0,0,,See you in two weeks.

Dialogue: 0,0:09:56.30,0:10:00.00,Default,,0,0,0,,- Do you have to go? You'll be fine, Elsa. Dialogue: 0,0:10:38.94,0:10:40.70,Default,,0,0,0,,Elsa?

Dialogue: 0,0:10:40.74,0:10:43.96,Default,,0,0,0,,Please,i know you're in there

Dialogue: 0,0:10:44.54,0:10:47.36,Default,,0,0,0,,People are asking $/$ where you've been,

Dialogue: 0,0:10:48.54,0:10:51.92,Default,,0,0,0,, They say have courageland i'm trying to... Dialogue: 0,0:10:51.96,0:10:56.50,Default,,0,0,0,,I'm right out here for you. Just let me in.

Dialogue: 0,0:10:57.30,0:10:59.58,Default,,0,0,0, We only have each other.

Dialogue: 0,0:10:59.72,0:11:01.80,Default,,0,0,0,,It's just you and me.

Dialogue: 0,0:11:02.02,0:11:05.26,Default,,0,0,0,, What are we gonna do?

Dialogue: 0,0:11:10.02,0:11:12.82,Default,,0,0,0,,Do you want to build a snowman? 